\title{
RNA in situ hybridization of dissected gonads*
}

\author{
Min-Ho Lee ${ }^{\S \dagger}$, Tim Schedl ${ }^{\S}$, Department of Genetics, Washington \\ University School of Medicine, St. Louis, MO 63110 USA
}

\section{Table of Contents}

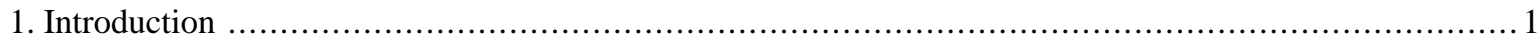

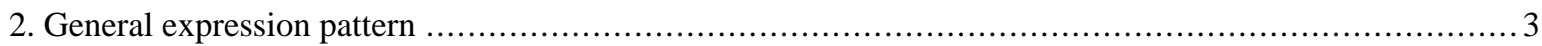

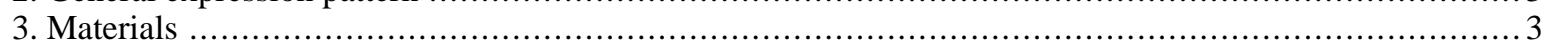

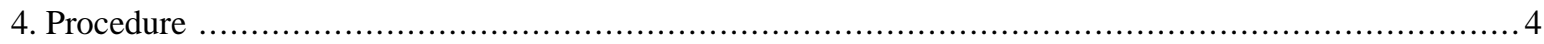

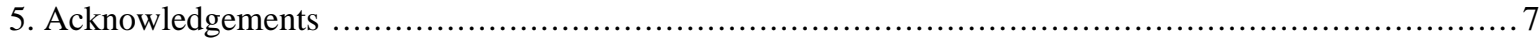

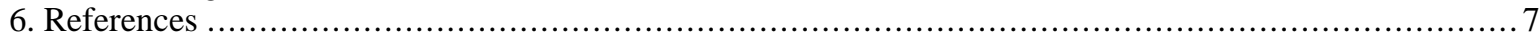

\section{Introduction}

Determination of the temporal and spatial pattern of gene expression is an important step in understanding gene function during $C$. elegans development. The expression pattern of a gene can be examined in several ways including transgenic reporter fusions (e.g., gfp, $\beta$-galactosidase), as well as immunohistochemistry and RNA in situ hybridization for analysis of the endogenous protein and mRNA, respectively. While reporter fusions and immnohistochemistry require time and effort to generate reagents (reporter construction and generation of transgenic lines or antibody production), RNA in situ hybridization only requires the transcribed region of a gene of interest. In addition, as a complement to protein expression patterns of a gene, RNA in situ allows one to determine whether the mRNA is subjected to post-transcriptional controls such as differential RNA localization, stability, and/or translational regulation (Evans et al., 1994; Seydoux and Fire 1994; Jones et al., 1996; Lee and Schedl 2001, 2004).

Several in situ hybridization protocols have been developed to detect RNA in C. elegans. RNA in situ in embryos is well described previously (Seydoux and Fire, 1995. Protocols for whole-mount in situ of intact animals and embryos can be also found at Yuji Kohara's website. Fluorescence RNA in situ hybridizations have been also described (Albertson et al., 1995; Graves, et al., 1999; Pitt et al., 2000). In this chapter, a protocol for detection of mRNA by in situ hybridization to dissected gonads is described. This protocol is primarily based on the method of Seydoux and Fire (1995) as adapted for dissected gonads.

\footnotetext{
*Edited by Oliver Hobert. WormMethods editor, Victor Ambros. Last revised May 3, 2005. Published June 14, 2006. This chapter should be cited as: Lee, M.-H. and Schedl, T. RNA in situ hybridization of dissected gonads (June 14, 2006), WormBook, ed. The C. elegans Research Community, WormBook, doi/10.1895/wormbook.1.107.1, http://www.wormbook.org.

Copyright: (C) 2006 Min-Ho Lee and Tim Schedl. This is an open-access article distributed under the terms of the Creative Commons Attribution License, which permits unrestricted use, distribution, and reproduction in any medium, provided the original author and source are credited.

${ }^{\S}$ To whom correspondence should be addressed. E-mail: mhlee@albany.edu or ts@genetics.wustl.edu

${ }^{\dagger}$ Current address: Department of Biological Sciences, University at Albany, SUNY, Albany, NY 12222
} 
In contrast to an earlier method described for dissected gonads wherein the gonads were affixed to slides (Crittenden et al., 1994), the various manipulations described below (gonad dissections, hybridizations, and washes) are all performed in solution, either in glass dishes (dissection) or in small glass tubes (hybridization). Washes are done by low-speed spins and all solutions (except fixatives) contain $0.1 \%$ Tween 20 to prevent dissected gonads from sticking to glass. A key to make this protocol work consistently is to fix dissected gonads in a combination of paraformaldehyde (3\%) and glutaraldehyde $(0.25 \%)$. The addition of glutaraldehyde results in a lower background, as compared to fixation with paraformaldehyde alone and makes gonads both less sticky and less susceptible to breakage.

It is important to perform RNA in situ hybridization using both sense and anti-sense probes for a gene of interest, at least for initial experiments. RNA in situ hybridization with a sense probe should give little or no signal compared to that with an anti-sense probe (Figure 1). The sense probe background control is particularly important for detecting transcripts that are expressed at very low levels, which requires an extended developing time with the alkaline phosphatase-mediated detection system. In general, we can easily detect most mRNAs that have five or more EST clones reported in WormBase. For mRNAs that have less than two EST clones (therefore likely expressed at very low levels), it is helpful to concentrate the probe either by using more template in the asymmetric PCR (probe synthesis step) or by dissolving the digoxigenin (DIG) labeled probe in a smaller volume. RNA in situ hybridization with a concentrated anti-sense probe usually results in increased signal with decreased developing time of the alkaline phosphatase-mediated detection system. In addition, concentration of the sense probe does not increase the background signal significantly.

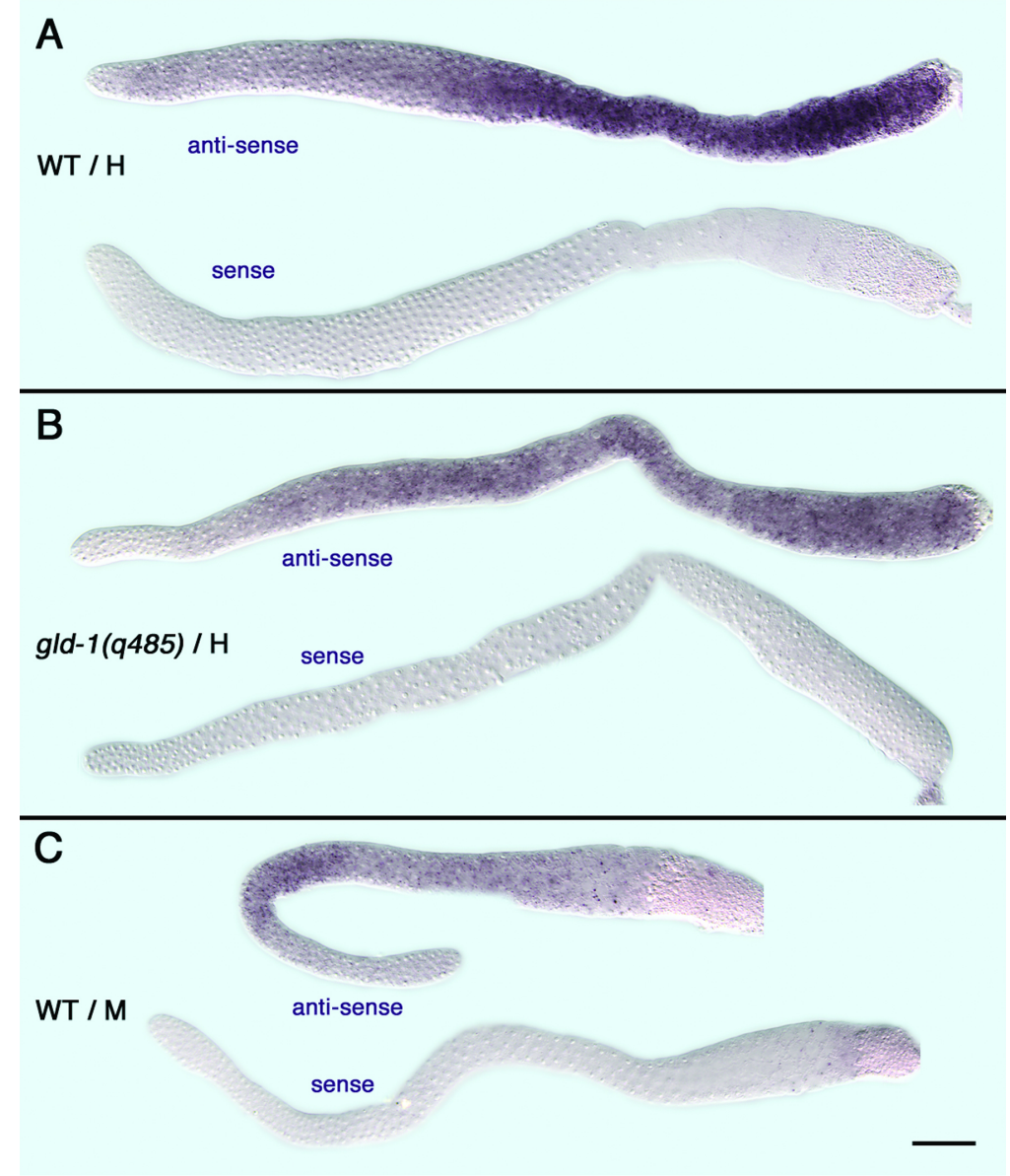

Figure 1. Gemline RNA in situ hybridization with an anti-sense and a sense probes. Representative photomicrographs of RNA in situ hybridizations showing cep-1/p53 mRNA accumulation in wild-type (A) and gld-l(null) (B) hermaphrodites, and wild-type male (C). Each panel has images from gonads hybridized with an anti-sense probe and a sense probe otherwise treated equally. Each image shows a surface view of the gonad where the distal region is on the left and the proximal region is on the right. Sense probe gave no or very little signals (the proximal signal is likely due to endogenous phosphatases). In wild-type hermaphrodites, cep-1 mRNA accumulates throughout the germ line and its levels increase toward the proximal region of the germ line. In gld-1(null), cep-1 mRNA levels are slightly lower as compared with wild type. In wild-type males, cep-1 mRNA accumulates at higher levels only in the distal meiotic germ cells, showing sexual dimorphism. 


\section{General expression pattern}

The levels of most maternal mRNAs become higher in the middle of the pachytene region and remain high in the developing oocytes in the proximal region because the bulk of RNA synthesis for oogenesis occurs in pachytene stage germ cells, with progressively less RNA synthesis as germ cells proceed through the diplotene stage. As chromosomes become highly condensed in late stage oocytes (diakinesis), almost no de novo RNA synthesis occurs (Gibert et al., 1984; Schisa et al., 2001) and RNA polymerase II becomes inactive (Kelly et al., 2002). Therefore, most maternal mRNAs are transcribed primarily in pachytene stage germ cells in the distal region and transported into the common cytoplasmic core. In the proximal region, maternal mRNAs are packaged into growing oocytes. These processes result in extensive RNA accumulation throughout pachytene stage germ cells and developing oocytes (Figure 1).

Some mRNAs are expressed throughout the germline including the distal mitotic region (e.g., glp-1) while others are only expressed in meiotic cells (e.g., rme-2). For a number of transcripts expressed throughout the germline, the relative levels observed in the distal mitotic region are lower, compared to the levels in the meiotic pachytene cells and proximal oocytes (Figure 1). The difference is likely, at least in part, a reflection of a lower level of the mRNA/protein being required for function in the distal mitotic region, while a higher level is required for late oogenesis and/or maternally for early embryogenesis.

\section{Materials}

Solutions do not need to be treated with diethyl pyrocarbonate.

PBS: Make a 10x stock solution according to Sambrook et al. (1989).

PBTw: 1x PBS containing $0.1 \%$ Tween 20 .

Paraformaldehyde / glutaraldehyde fix:Paraformaldehyde/Glutaraldehyde fixation works well for germline RNA in situ: gonads remain intact through an extensive protease treatment $(50 \mu \mathrm{g} / \mathrm{ml}$ Proteinase $\mathrm{K}$ for 30 min at room temperature (RT) that would destroy gonads fixed in paraformaldehyde alone. This fixation can also be used with good results for histological staining with some antibodies.

To make $3 \%$ paraformaldehyde / $0.25 \%$ glutaraldehyde / $0.1 \mathrm{M} \mathrm{K}_{2} \mathrm{HPO}_{4}(\mathrm{pH} 7.2)$, mix

1. $10 \mathrm{ml} 16 \%$ formaldehyde (sealed ampoules from EM Sciences \#15710)

2. $\quad 0.53 \mathrm{ml} 25 \%$ glutaraldehyde (sealed ampoules from EM Sciences \#16220)

3. $25 \mathrm{ml} \mathrm{0.2} \mathrm{M} \mathrm{K}_{2} \mathrm{HPO}_{4}(\mathrm{pH} 7.2)$

and dispense in $10 \mathrm{ml}$ aliquots and store at $-20^{\circ} \mathrm{C}$.

Proteinase K: $20 \mathrm{mg} / \mathrm{ml}$. Dispense in $10 \mu \mathrm{l}$ aliquots and store at $-80^{\circ} \mathrm{C}$. Do not refreeze, discard after use.

Hybridization buffer: 5X SSC, $50 \%$ deionized formamide, $100 \mu \mathrm{g} / \mathrm{ml}$ autoclaved Herring sperm DNA, 50 $\mu \mathrm{g} / \mathrm{ml}$ Heparin and $0.1 \%$ Tween-20. We make $50 \mathrm{ml}$, dispense in $10 \mathrm{ml}$ aliquots and store at $-20^{\circ} \mathrm{C}$.

Alkaline-phosphatase-conjugated anti-DIG (Fab2 fragment) from Roche (\#1 093 274): An optimal dilution of this antibody needs to be determined empirically as lot-to-lot variations may exist. We have been using dilutions from 1:1000 to $1: 2500$.

Staining Solution: $100 \mathrm{mM} \mathrm{NaCl} ; 5 \mathrm{mM} \mathrm{MgCl}$; $100 \mathrm{mM}$ Tris (pH 9.5); 0.1\% Tween 20; $1 \mathrm{mM}$ Levamisole. Levamisole is a potent inhibitor of endogenous phosphatases.

Sigma Fast BCIP/NBT tablet (\#B5655): Dissolve one tablet in $10 \mathrm{ml}$ staining solution. If non-specific background signal is high, you may want to use more staining solution (up to $20 \mathrm{ml}$ ) to dissolve the tablet.

Anti-Fade solution: Make 0.2M Dabco (Sigma \#D2522) in $20 \mathrm{mM}$ Tris (pH 8.0), which can be stored at $-20^{\circ} \mathrm{C}$. Then dilute this solution $(10 \%)$ in glycerol $(90 \%)$ and store $-20^{\circ} \mathrm{C}$. 
Culture tubes: Borosilicate glass tubes with plain end. These tubes can be baked to decontaminate RNase. Available from Fisher as $6 \mathrm{~mm}$ (O.D.) x $50 \mathrm{~mm}$ (length) in either Pyrex (Fisher \#14-957AA) or Kimax (Fisher \#14-925B) brands.

Dissection dishes: We use Square Watch Glass from Carolina Biological Supply (\#ER-74-2300). primers.

QIAquick PCR Purification kit from Qiagen (\#28104): Works well to remove unincorporated dNTP and PCR

DIG DNA Labeling Mix, 10 x conc.: Roche (\#1 277 065).

\section{Procedure}

Single-stranded probes from cloned cDNA can be prepared anytime. Following dissections and fixation, fixed gonads can be stored in $100 \% \mathrm{MeOH}$ at $-20^{\circ} \mathrm{C}$ for at least one week. Once the gonads are subjected to permeabilization, the remaining procedure has to be completed.

Procedure 1. Preparation of single-stranded probes from cloned cDNA

Based on Patel and Goodman (1992), with slight modifications.

\section{PCR amplification of a cDNA of interest with any set of primers.}

A cloned cDNA template is optimal because amplified products from genomic DNA usually generate high background.

Use less than $1 \mu \mathrm{l}(10 \mathrm{pmole} / \mu \mathrm{l})$ of primers because QIAquick PCR Purification kit will not effectively remove primers if the concentration is higher.

We usually set up two $50 \mu \mathrm{PCR}$ reaction with 35 cycles $\left(94^{\circ} \mathrm{C} 30\right.$ seconds, $55^{\circ} \mathrm{C} 30$ seconds and $72^{\circ} \mathrm{C}$, 1 minute/1 kb).

$\begin{array}{ll}\text { 10x Taq Buffer } & 5.0 \mu \mathrm{l} \\ \text { dNTP mix }(2.5 \mathrm{mM} \text { each }) & 2.0 \mu \mathrm{l} \\ \text { 5'Primer }(10 \mathrm{pmole} / \mu \mathrm{l}) & 1.0 \mu \mathrm{l} \\ \text { 3'Primer }(10 \mathrm{pmole} / \mu \mathrm{l}) & 1.0 \mu \mathrm{l} \\ \text { a cloned cDNA }(1: 50 \text { dilution of miniprep DNA) or } & 2.0 \mu \mathrm{l} \\ \text { 5-10 ng of purified plasmid } & \\ \text { Taq Polymerase } & 2 \text { units } \\ \mathrm{ddH}_{2} \mathrm{O} & \text { to } 50 \mu \mathrm{l}\end{array}$

Run $3 \mu$ leach in an agarose gel; the PCR product must be an intense single band.

\section{Purification of PCR product}

Use the QIAquick PCR Purification kit to purify the PCR product away from unincorporated dNTP and PCR primers. Elute with $25 \mu \mathrm{l}$ Elution buffer. The concentration should be above $200 \mathrm{ng} / \mu \mathrm{l}$.

\section{Asymmetric (one-way) PCR}

To generate DIG labeled probe $\left(35\right.$ cycles, $94^{\circ} \mathrm{C} 30$ seconds, $55^{\circ} \mathrm{C} 30$ seconds and $\left.72^{\circ} \mathrm{C}, 1 \mathrm{minute} / 1 \mathrm{~kb}\right)$ :

10x Taq Buffer

DIG DNA Labeling Mix, $10 \mathrm{x}$ conc

Primer $^{\ddagger}(10 \mathrm{pmole} / \mu \mathrm{l})$

Purified PCR product (at least $200 \mathrm{ng} / \mu \mathrm{l}$ )
$2.5 \mu 1$

$2.5 \mu 1$

$1.0 \mu 1$

$4.0 \mu 1$

Use only one primer. We set up two reactions, one to generate a sense probe with 5'primer and the other to generate an anti-sense probe with 3 'primer. RNA in situ hybridization with the sense probe will be a background control. 
Taq Polymerase 2 units

$\mathrm{ddH}_{2} \mathrm{O}$ to $25 \mu \mathrm{l}$

4. $75 \mu \mathrm{l}$ of $\mathrm{H}_{2} \mathrm{O}$ is added to the reaction and $90-95 \mu \mathrm{l}$ of the diluted reaction is transferred to a new tube.

5. $10 \mu \mathrm{l}$ of $1 \mathrm{M} \mathrm{NaCl}$ and 3 vols of $100 \% \mathrm{EtOH}$ are added to the diluted reaction. After $30 \mathrm{~min}$ at $-70^{\circ} \mathrm{C}$ or overnight at $-20^{\circ} \mathrm{C}$, the reaction is centrifuged at $14,000 \mathrm{rpm}$ for $10 \mathrm{~min}$. The pellet is washed in $70 \%$ ethanol, dried, and resuspended in $400 \mu$ l of hybridization buffer.

6. The probe is boiled for $1 \mathrm{hr}$. This step reduces the length of the probe for efficient penetration.

7. Probes can be stored at $-20^{\circ} \mathrm{C}$ for a long period. We have used two year-old probe without any obvious reduction of signal.

Procedure 2. Dissections and fixation

1. Wear latex gloves (optional), prepare dissected gonads (see http://www.genetics.wustl.edu/tslab/ gonad_dissections.html for dissection) and fix in $3 \%$ paraformaldehyde / $0.25 \%$ glutaraldehyde / $0.1 \mathrm{M}$ $\mathrm{K}_{2} \mathrm{HPO}_{4}$ (pH7.2) for 1.5 to $2 \mathrm{hr}$ at RT. We routinely dissect about 150 animals per each hybridization to obtain $40^{2}$ or more gonads that are completely extruded, well stained, and unbroken at the end of the entire procedure.

2. Transfer entire contents to a $5 \mathrm{ml}$ glass conical tube and spin in clinical table top centrifuge for $1 \mathrm{~min}$ at setting 3 (All subsequent spins are also for 1 min at setting 3).

3. Discard the fixative in the appropriate chemical waste container and resuspend in 2-4 ml PBTw.

4. Spin and discard PBTw as much as possible.

5. Add about $2 \mathrm{ml}$ of $100 \%$ cold $\left(-20^{\circ} \mathrm{C}\right)$ Methanol $(\mathrm{MeOH})$. At this point, dissected gonads can be stored in $100 \% \mathrm{MeOH}$ at $-20^{\circ} \mathrm{C}$ for at least one week with no obvious problems.

Procedure 3. Permeabilization: Proteinase K digestion

1. Add 2-3 $\mathrm{ml}$ of PBTw to the $\mathrm{MeOH}$ solution, and spin. Wash twice in PBTw. Now split the sample into 2 or more tubes (either into $5 \mathrm{ml}$ conical tubes or into $6 \mathrm{~mm}$ x $50 \mathrm{~mm}$ culture tubes).

2. Using a $20 \mathrm{mg} / \mathrm{ml}$ stock of Proteinase $\mathrm{K}$ (PrK), make solutions of $50 \mu \mathrm{g} / \mathrm{ml}$ PrK in PBTw. Add $2 \mathrm{ml}$ PrK / PBTw and digest for $30 \mathrm{~min}$ at RT.

3. Wash three times in PBTw.

4. Fix 15 min in $3 \%$ paraformaldehyde / $0.25 \%$ glutaraldehyde / $0.1 \mathrm{M} \mathrm{K} \mathrm{HPO}_{4}(\mathrm{pH} 7.2)$

5. Incubate $15 \mathrm{~min}$ in PBTw containing $2 \mathrm{mg} / \mathrm{ml}$ glycine.

6. Wash three times in PBTw.

7. Divide gonads among several $6 \times 50 \mathrm{~mm}$ culture tubes, one tube per hybridzation.

Procedure 4. Hybridization and wash

1. Place gonads in $400 \mu \mathrm{l}$ of $50 \%$ PBTw / $50 \%$ hybridization buffer (HB) and incubate 5 min at $48^{\circ} \mathrm{C}$ (in water bath).

2. Pre-hybridize in $400 \mu \mathrm{HB}$ for $1 \mathrm{hr}$ at $48^{\circ} \mathrm{C}$.

3. Dilute boiled probe in HB to give $100 \mu \mathrm{l}$ of solution. Try a 1:2 dilution for probes to messages of unknown abundance. Experience with gld-1 probes suggests that probe dilution is not critical - a strong, clean signal was 
obtained at dilutions between 1:2 and 1:5, but it began to fall off at 1:10. Probe to major sperm protein RNA, which is very abundant during spermatogenesis, could be diluted 1:20 without any fall off in signal.

4. Boil diluted probe $5 \mathrm{~min}$, cool to $48^{\circ}$, and add to gonads.

5. Hybridize for 12 to $36 \mathrm{hr}$ at $48^{\circ} \mathrm{C}$ (longer hybridization times tend to give increased signal and lower background). We routinely hybridize for $36 \mathrm{hrs}$.

6. Wash three times in PBTw.

7. Divide gonads among several 6 x $50 \mathrm{~mm}$ culture tubes, one tube per hybridzation.

8. Add $400 \mu \mathrm{l}$ of $\mathrm{HB}$ that is pre-warmed to $48^{\circ}$, spin down, and remove supernatant.

9. Divide gonads among several $6 \times 50 \mathrm{~mm}$ culture tubes, one tube per hybridzation.

10. Wash $4 \times 15 \mathrm{~min}$ in $\mathrm{HB}$ at $48^{\circ} \mathrm{C}$.

11. Then perform the following washes:
a. $1 \times 10 \min$ in $50 \% \mathrm{HB} / 50 \% \mathrm{PBTw}$ at $48^{\circ}$
b. $2 \times 10 \mathrm{~min}$ in PBTw at $48^{\circ}$
c. $\quad 1 \times 5$ min in PBTw at RT

Procedure 5. Probe detection

1. Incubate $15 \mathrm{~min}$ in PBTw $/ 0.5 \mathrm{mg} / \mathrm{ml}$ BSA (either fraction $\mathrm{V}$ or restriction enzyme grade).

2. Dilute alkaline-phosphatase-conjugated anti-DIG (Fab2 fragment) to optimal conc. in PBTw /BSA. Add $500 \mu 1$ to each tube and incubate overnight at $4^{\circ} \mathrm{C}$ or at RT for $2 \mathrm{hr}$. For gonads, overnight at $4{ }^{\circ} \mathrm{C}$ is definitely better than $2 \mathrm{hr}$ at RT.

3. Wash at RT as follows:
a. $\quad 2 \times 2$ min PBTw
b. $3 \times 20$ min PBTw / BSA
c. $2 \times 5$ min in Staining solution.

4. Transfer gonads to staining solution with BCIP/NDT and $100 \mathrm{ng} / \mathrm{ml}$ DAPI and cover to protect from light. Signal will come up anywhere between $5 \mathrm{~min}$ and $6 \mathrm{hr}$. For convenience, the reaction can be monitored by transferring tube contents to a glass dish and inspecting periodically under the dissecting scope. However, stain will appear darker in the dissecting scope than under Nomarski optics with a 40X or higher lens.

5. Stop the reaction by washing three times in PBTw. Finally place gonads in PBS containing $100 \mathrm{ng} / \mathrm{ml}$ DAPI.

6. After removing DAPI solution as much as possible, add $35 \mu \mathrm{l}$ anti-fade solution.

Procedure 6. Mounting gonads for viewing

- Using a drawn capillary pipette, transfer settled worms onto a large $2 \%$ agar pad that covers most of a slide. After drawing off excess liquid with a capillary, an eyelash hair can be used to push gonads and intestines away from one another. Cover with a large $(24 \times 50 \mathrm{~mm})$ coverslip, taking care not to move the coverslip once in place. Also do not seal the coverslip immediately - image may improve as liquid evaporates and gonads become somewhat flattened. We usually take images after storing the slides at $4^{\circ} \mathrm{C}$ overnight without sealing. 
Bright field (Nomarski) images must be taken before DAPI images because the strong UV light focused by the microscope literally burns gonads brown. Slides can be stored at $4^{\circ} \mathrm{C}$ for a week or more, particularly if sealed with nail polish around the periphery of the coverslip. Because the stain is purplish, images are better in color than in black and white.

\section{Acknowledgements}

We are grateful to Ross Francis for establishing this protocol and members of the Schedl lab for comments on this review. Work in the TS lab is supported by NIH grant GM63310.

\section{References}

Albertson, D.G., Fishpool, R.M., and Birchall, P.S. (1995). Fluorescence in situ hybridization for the detection of DNA and RNA. Methods Cell Biol. 48, 339-364. Abstract

Crittenden, S.L., Troemel, E.R., Evans, T.C., and Kimble, J. (1994). GLP-1 is localized to the mitotic region of the C. elegans germ line. Development 120, 2901-2911. Abstract

Evans, T.C., Crittenden, S.L., Kodoyianni, V., and Kimble, J. (1994). Translational control of maternal $g l p-1$ mRNA establishes an asymmetry in the C. elegans embryo. Cell 77, 183-194. Abstract Article

Gibert, M.A., Starck, J., and Beguet, B. (1984). Role of the gonad cytoplasmic core during oogenesis of the nematode Caenorhabditis elegans. Biol. Cell 50,77-85. Abstract

Graves, L.E., Segal, S., and Goodwin, E.B. (1999). TRA-1 regulates the cellular distribution of the tra-2 mRNA in C. elegans. Nature 399, 802-805. Abstract Article

Jones, A.R., Francis, R., and Schedl, T. (1996). GLD-1, a cytoplasmic protein essential for oocyte differentiation, shows stage- and sex-specific expression during Caenorhabditis elegans germline development. Dev. Biol. 180, 165-183. Abstract Article

Kelly, W.G., Schaner, C.E., Dernburg, A.F., Lee, M.H., Kim, S.K., Villeneuve, A.M., and Reinke, V. (2002). $\mathrm{X}$-chromosome silencing in the germline of C. elegans. Development 129, 479-492. Abstract

Lee, M.H., and Schedl, T. (2001). Identification of in vivo mRNA targets of GLD-1, a maxi-KH motif containing protein required for C. elegans germ cell development. Genes Dev. 15, 2408-2420. Abstract Article

Lee, M.H., and Schedl, T. (2004). Translation repression by GLD-1 protects its mRNA targets from nonsense-mediated mRNA decay in C. elegans. Genes Dev. 18, 1047-1059. Abstract Article

Patel, N.H., and Goodman, C.S. (1992). Preparation of digoxigenin-labeled single-stranded DNA probes. In: Non-Radioactive Labeling and Detection of Biomolecules, C. Kessler, ed. (Berlin: Springer-Verlag).

Pitt, J.N., Schisa, J.A., and Priess, J.R. (2000). P granules in the germ cells of Caenorhabditis elegans adults are associated with clusters of nuclear pores and contain RNA. Dev. Biol. 219, 315-333. Abstract Article

Sambrook, J., Fritsch, T., and Maniatis, T. (1989). Molecular cloning: a laboratory manual. 2nd edition. (New York: Cold Spring Harbor Laboratory Press).

Schisa, J.A., Pitt, J.N., and Priess, J.R. (2001). Analysis of RNA associated with P granules in germ cells of $C$. elegans adults. Development 128, 1287-1298. Abstract

Seydoux, G., and Fire, A. (1994). Soma-germline asymmetry in the distributions of embryonic RNAs in Caenorhabditis elegans. Development 120, 2823-2834. Abstract

Seydoux, G., and Fire, A. (1995). Whole-mount in situ hybridization for the detection of RNA in Caenorhabditis elegans embryos. Methods Cell. Biol. 48, 323-337. Abstract

All WormBook content, except where otherwise noted, is licensed under a Creative

SOMERERIGHIS RESERVED Commons Attribution License. 